\title{
If Not Here, Where? Understanding Teachers' Use Of Technology
In Silicon Valley Schools
}

\author{
Pedro Hernández-Ramos \\ Santa Clara University
}

\begin{abstract}
This article presents results of a survey conducted in the spring of 2004 of practicing teachers in K-12 schools in Santa Clara County, California, also known as "Silicon Valley." Exposure to technology in teaching preparation programs, knowledge of software applications, and constructivist beliefs were found to be positively related to more frequent use of technology by teachers, both for themselves and their students. Other factors such as availability of technical support also seem to affect frequency of technology use. It is argued that the individual teachers do not mainly determine technology integration in $K-12$ classrooms, even in technology-centric regions such as Silicon Valley, but that other technology-specific and contextual factors also play critical roles. (Keywords: Teachers' use of technology, technology integration, K-12 teachers, teacher preparation, constructivist beliefs.)
\end{abstract}

\section{INTRODUCTION}

Are teachers in California's "Silicon Valley," recognized around the world as a powerful engine for technological advancement, more likely to integrate technology in their classrooms? Can the social, economic, and cultural environment of a region have a measurable effect on the levels of technology integration by teachers in K-12 schools? Cuban, Kirkpatrick, and Peck (2001), among others, have wondered about the low use of technology by teachers in schools with what seem like adequate levels of access to technology, particularly in social and cultural environments such as Silicon Valley ("the heart of technological progress" according to Cuban et al.) where a significant proportion of businesses are in the "high tech" sector. Somehow, the expectation is that given the region's main business (technology), teachers working here will make more use of technology in their classrooms. One of the goals of this survey of practicing K-12 teachers in Santa Clara County-which comprises Silicon Valley-is to offer a more nuanced explanation for the levels of technology use observed in Silicon Valley schools, and probably elsewhere as well, and draw some implications for teacher preparation, staff development efforts, and education reform.

\section{Theoretical Background}

The problem of access to technology (at least in raw numbers) in American schools seems less relevant as districts and schools continue purchasing computers and related equipment in great numbers. In an evaluation report prepared for a Pennsylvania district that implemented a laptop program for all students in grades 3-12, Kerr, Pane, and Barney (2003) said, 
As of 2001, American public schools housed more than 10 million computers, with 99 percent of schools and 87 percent of classrooms connected to the Internet, and one Internet-wired computer for every 5.4 students (Kleiner and Farris, 2002). Pervasive educational technology has increased access and use to unprecedented levels.

Ninety-seven percent of teachers reported using computers for educational purposes in 2001, while 53 percent reported using software in their classroom instruction (Fouts, 2000). (p. 10)

Cuban (2001) and Cuban, Kirkpatrick, and Peck (2001) have raised the question of what is the return on such large technology investments, from a financial as well as from a teaching and learning perspective. However, in order to evaluate the true effect of technology in education settings, one should go beyond questions of access (e.g., how many computers are there in the school, and are they connected to the Internet or not), to the more difficult questions of availability (e.g., do the computers work? Do they have good software? Is there good technical support at the school?) and integration (e.g., have teachers been prepared to use technology effectively in their classrooms? Are they using technology for both personal productivity and to support and enhance student learning?) (National Center for Education Statistics, 2002). These questions allow us to look beyond the individual (teacher) level, to comprise the broader contexts within which teacher classroom practices must be located.

In her excellent history of electric communication at the end of the nineteenth century, Marvin (1988) wrote, "The history of media is never more or less than the history of their uses, which always lead us away from them to the social practices and conflicts they illuminate" (p. 8). In a similar vein, it may be argued that our struggles to make sense of the presence of computers and related technologies (such as the Internet) in the classroom have less to do with the technologies themselves than with the school practices, educational cultures, and power struggles among stakeholders in the process. Thus, one of the purposes of this research is to provide insights into the perspectives of one of those stakeholders - teachers - who have been traditionally placed in the position of "gatekeepers" in educational change processes (e.g., Cuban, 1993).

Among many other insights, what large-scale, long-term projects like the Apple Classrooms of Tomorrow (ACOT, 1995) research program contributed to our understanding of technology (broadly defined) in education is that technology by itself will not "cure" all that ails education (contrary to what optimists like to believe) nor is it the source of all evils (as critics and pessimists like to assert) (Fisher, Dwyer, \& Yocam, 1996). In particular, ACOT and other research efforts since the late 1980s have made clear the central role that teachers play in any reform efforts whether these efforts involve technology or not, but also identified the decisive influence that other stakeholders (including school principals, parents, district boards, and state legislatures) and other factors (such as access to staff development and ongoing technical support) play in the process. When the reform involves technology, we now know that the true possibilities for transformation come not from the technologies (computers, the Internet, 
video, and so on) themselves, but from the deep changes in school organization and in teachers' beliefs and pedagogical practices (Dwyer, Ringstaff, \& Sandholtz, 1990a, 1990b) that the introduction of technology may catalyze. Thus, although the five stages of evolution in teacher practices concerning technology (entry, adoption, adaptation, appropriation, and invention) that ACOT identified through longitudinal research (Sandholtz, Ringstaff, \& Dwyer, 1997) seem focused on the teacher's personal journey of transformation, the underlying context for such a transformation (the school environment and its resources, support from the administration, collegial environment, and so on) is a necessary condition without which any one individual's technology integration is either stunted or much longer than under ideal conditions. Most schools and districts engage in piece-meal efforts at technology integration, expecting huge payoffs in student achievement from what may be, in fact, very modest investments in structural changes.

An emphasis on pedagogical knowledge over technical skills (Sandholtz \& Reilly, 2004) suggests that the more that teachers know about how students learn (Bransford, Brown, \& Cocking, 2000), the more they will be able to employ a variety of teaching strategies-including a wide range of technology-based tools - to address the learning needs of every student. So part of the challenge at hand consists in identifying the pedagogical theories and practices that are best suited to assist teachers in creating learning environments where all learners can flourish, with access to resources and tools (including technology) that effectively support both the teachers' practice and the students' learning.

\section{Understanding Levels of Technology Integration}

Every school and district can be seen as an "ecosystem" (Zhao \& Frank, 2003) that influences the levels of teachers' and students' computer use within it. Although Zhao and Frank (2003) found in their study that "most of the variation in computer use fell within ecosystems rather than between them" (p. 823), other research (e.g., Achinstein, Ogawa, \& Speiglman, 2004) found differences in the "level of teacher control over instruction" (p. 591) among districts, (and by extension, among schools) and supports the notion that "district contexts deeply affect teacher learning" (p. 594).

To counter the influence of local context, some recent technology projects have distributed resources equally among entire target populations. For example, in 2001, the Maine Learning Technology Initiative (MLTI) embarked on an ambitious program to provide laptop computers to all 7th and 8th grade students and their teachers (Beaudry, 2004; Silvernail \& Lane, 2004). By 2004, "34,000 students and 3,000 teachers" (Silvernail \& Lane, 2004) had received computers, and the first evaluation results were being published. Not surprisingly, among the findings are outcomes (Silvernail \& Lane, 2004) showing that teachers with higher computer literacy levels, "who have participated in more professional development workshops and activities" (p. 11), and who have had the computers for a longer time are integrating technology into their teaching to a higher degree, mainly for "developing instructional materials, conducting research related to their instruction, and communicating with colleagues" (p. 
9). Other findings reported by Silvernail and Lane (2004) suggest that the combination of complete access (everyone has a laptop computer) and availability (e.g., of relevant software, professional development, and technical support) is resulting in higher integration levels than would be observed otherwise. In their terms, "the more experience the teachers have with the laptops, the greater the impact on their curriculum and instruction" (p. 16). Similar results, although more anecdotal in nature, have been observed in the laptop program in Henrico County, Virginia, which has distributed about 28,000 laptops to middle school students and teachers (Henrico County Public Schools, 2004).

In Silicon Valley, Cuban, Kirkpatrick, and Peck (2001) earlier studied two high schools in California in the late 1990s, by which time the levels of access to technology (computers with Internet access, mostly in media centers or labs) in these two schools were above both state and national averages. However, their data revealed that "there was a general lack of technology usage among teachers in classrooms, labs, and media centers" (p. 821), as no more than one third of teachers "accounted for $60-70 \%$ of all machine use in the media centers" (p. 820). Although high, the ratio of students to computers at these high schools was not one to one as in Maine.

Given that access is not considered a problem, Cuban et al. (2001) concluded that a combination of two main factors can be invoked to account for the lack of integration: first, problems with the technologies themselves, and the need for "substantial changes in teaching practices" (p. 830). The second factor, in particular, places teachers as the key "gatekeepers" or spoilers in the process, as it is their lack of change that is often blamed for the lack of integration. Using different terminology to address similar issues, Ertmer (1999) identified first- and second-order barriers limiting teachers' technology integration, where first-order barriers are extrinsic to teachers (access, time, support) and second-order barriers are intrinsic (beliefs, practices, willingness to change). Broadening the scope, Ringstaff and Kelly (2002) summarized the conditions required to see effective technology integration by teachers in schools:

- Changing teacher beliefs about teaching and learning

- Sufficient and accessible equipment

- Placement: classrooms vs. labs

- Computer [and network] access at home

- Long-term planning

- Technical and instructional support

- Technology integrated within the curricular framework.

Furthermore, through their research in Michigan schools, Zhao, Pugh, Sheldon, and Byers (2002) identified 11 factors grouped into three dimensions that influenced the degree of success in implementation of technology projects in K-12 classrooms. Three factors were related to the "innovators" (teachers): technology proficiency, pedagogical compatibility, and social awareness. Four factors were related to the "innovation" (technology): Distance from school culture, distance from existing practice, distance from available technological resources, 
and dependence on others. And three factors were related to the "context" (school): Human infrastructure, technological infrastructure, and social support. Zhao et al. (2002) posit bidirectional influences between all three dimensions, and the combined influences of all three on teachers' implementation success or failure.

\section{Research Framework}

The research reported here aims to provide a more comprehensive view of what Zhao et al. (2002) call "... the complex and messy process of technology integration in real classrooms" (p. 484), a process that starts not when teachers first come into their classrooms but before, in their personal lives and during their teacher preparation experiences. The circumstances teachers face in their schools, including availability of hardware and software, technical support, and the collegial environment will be examined as possible predictors of teachers' beliefs about constructivist teaching practices, as constructivism is the pedagogical philosophy that is most closely related to the " 21 st century skills" approach (Jonassen et al., 2003; Roblyer, 2003). Technology integration will be analyzed not only in terms of the teachers' personal use, but also in terms of their design of learning activities for the students in their classrooms.

\section{METHOD}

A total of 350 surveys were distributed to teachers in Santa Clara County. Telephone interviews were first conducted with district technology coordinators from all 32 elementary (21 districts), high school (5 districts), and unified (6) districts in the county to identify schools where, in the coordinator's experience, at least some teachers were using technology. From the 61 schools thus identified (28 elementary, 21 middle, 12 high schools), a weighted sample of teachers from different grade levels was drawn: 248 survey packets went to elementary school teachers, 59 to middle school teachers, and 43 to high school teachers. Given that as of July 2004 (Santa Clara County Office of Education, 2005) there were more elementary schools ( $243 \mathrm{~K}-5)$ than middle schools (59 6-8) and high schools (469-12), the number of teachers receiving the survey at each school selected varied, from as few as three in high schools to as many as 10 in elementary schools. In a cover letter to the principal of each school, instructions were provided to distribute the survey packets to teachers at random. To simplify the principals' job, random numbers were included taking into account the number of teachers at each school, instructing the principal to use the school's alphabetical list of full-time teaching staff.

Following the suggestions of Yammarino, Skinner, and Childers (1991) for survey procedures designed to increase response rate, the survey packets the teachers received included a cover letter describing the study, the questionnaire, a release form, a stamped self-addressed return envelope, and a $\$ 10$ gift card to a bookstore chain as a token of compensation for the approximately 30-45 minutes it took respondents to complete the survey. A total of 203 surveys were returned, for a response rate of 58 percent. Of these, 132 (66.7 percent) were elementary school $(\mathrm{K}-5)$ teachers, 45 (22.7 percent) were middle school (6-8) 
teachers, and 21 (10.6 percent) were high school (9-12) teachers. Five respondents did not answer this question. The survey is an eight-page questionnaire divided into six sections: Teaching Background (12 questions), Technology in Your Classroom (36 questions), Professional Development (24 questions), Proficiency with Technology (19 questions), Technology and You (24 questions), and About You (41 questions). (See Appendix A, page 56.) Past work by Becker (1994, 2000), Marcinkiewickz (1993-1994), and others informed the types of questions in the survey, including personal background and experiences, professional preparation, type of school, collegial environment, perceived efficacy with computers, perceived technical and staff development support, teaching beliefs and practices, and other factors. In addition, variables such as educational background, which have been researched before, were broadened to include specifically the respondents' exposure to technology during their teacher preparation, and whether they had observed the faculty in their program using technology at all, and also in memorable ways.

\section{DATA ANALYSIS}

This article presents data from the survey of Silicon Valley teachers on several major factors related to teachers' (and their students) use of technology in the classroom: Technical proficiency, personal and professional background, collegial environment, access to staff development and technical support, and authentic use of technology.

\section{Technical Proficiency}

A battery of three questions asked respondents (using a four-point Likert scale with no neutral point) to agree/disagree with the statements "I feel great confidence in my computer skills," "Working with computers make me anxious," and "I like learning and working with computers." These three items were combined into a Technology Self-Efficacy scale (Cronbach's Alpha $=.82)$. Males $(\mathrm{M}=$ 10.17) had a significantly higher average than females ${ }^{1}(M=9.09)$ in this scale $(\mathrm{F}(1,196)=8.136, \mathrm{p}=.005)$, once again suggesting that work needs to be done to increase women's comfort and confidence around technology (Becker, 1994).

Technical proficiency was also measured through questions on how long respondents had owned a personal computer and through the creation of a scale from questions where respondents were asked to rate themselves as users of 11 different software applications. Although there were no significant differences in Technology Self-Efficacy by length of time of PC ownership, knowledge of software applications yielded a different result. Teachers categorized as "Advanced" $(\mathrm{M}=11.07)$ users of software applications had significantly higher averages in the Technology Self-Efficacy scale than teachers who were "Novice" $(\mathrm{M}=7.67)$ or "Intermediate" $(\mathrm{M}=9.31)$ users $(\mathrm{F}(2,183)=60.590, \mathrm{p}=.000)$.

${ }^{1}$ A total of 200 respondents identified their gender: 85 percent female (170), 15 percent male (30). Thus, this survey is typical in reporting a teaching force made up largely of women, and a somewhat similar pattern of technology-related attitudes and experiences. 


\section{Personal and Professional Background}

Almost two-thirds of respondents (62.1 percent) reported having 10 years of teaching experience or less, and at the other end, 15.7 percent had 20 or more years of experience. Almost exactly one quarter of both female and male respondents had one to three years of experience.

With regard to technology in their teacher preparation program, 70 percent of respondents said they had been provided "exposure to, and use of, technology for teaching and learning." However, the proportion of faculty using technology that could be observed by their students was much lower. Figure 1 shows the proportion of faculty who used technology in respondents' teacher preparation programs. It is worth remarking on the fact that slightly more than half of respondents who said they had been exposed to technology in their programs still reported that either none (22.1 percent) or only one or two faculty members (31.6 percent) used technology. This suggests that much of their exposure probably took place in labs or outside of the classrooms, where faculty were less likely to be modeling technology integration strategies.

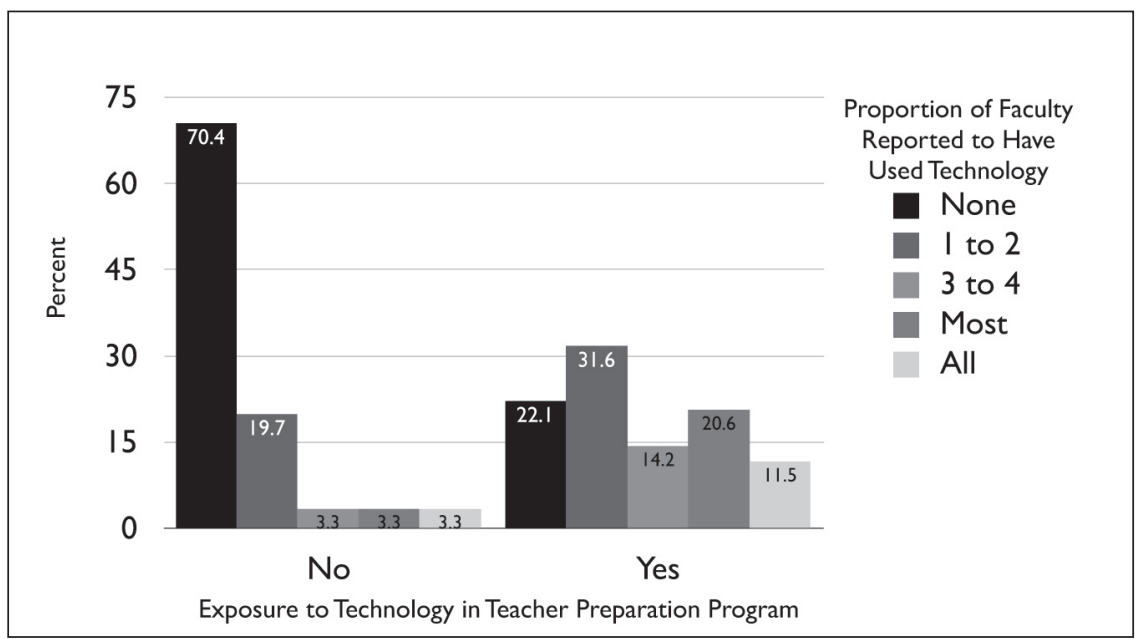

Figure 1. Proportions of Faculty Reported to Have Used Technology, By Exposure to Technology in Teacher Preparation Program.

\section{School and Classroom Context}

Practically all respondents who answered the question (185 out of 191, or 96.9 percent) reported that their classrooms had Internet access. However, 20 percent of teachers reported that their classrooms had no computers dedicated to student use, which probably means that it was only the teacher's computer that had access to the Internet.

Years of teaching experience also seem to influence teachers' attitudes toward technology integration. In answer to the question, "Do you integrate technology into your lesson plans whenever possible?" one would expect that younger teachers, with less experience but probably more technologically savvy, would indicate 
a greater willingness to integrate technology. However, the data reveal that fewer teachers with less than five years of experience ( 46.3 percent) answered "Yes," compared to those with 6-to-10 years of experience (73.8 percent) and those with 11 or more years of experience $(60.9$ percent $)($ Chi-Square $(4)=9.040, \mathrm{p}=.011)$.

The survey included a battery of three questions on respondents' experiences with technology during their teacher preparation program. Only one third (31 percent) of the male respondents and one quarter (24.3 percent) of the female respondents said that "technology was important" in their preservice program, so it was not surprising to see that a combined 65.5 percent of males and 68.2 percent of females either disagreed or strongly disagreed with the statement "My preservice teacher training program included teaching with technology methodologies that were beneficial to me." Equally consistent is the reporting of 56.7 percent of males and 66.9 percent of females that they did not "observe a practicing teacher use technology in his/her classroom in ways that inspired you to learn to do the same."

Exposure to technology in teacher preparation did create a significant difference in subsequent use by teachers of a computer to conduct lessons in the classroom, (61 percent for those with exposure, 47 percent for those without) and in having created technology-based projects for students: 72.5 percent of those exposed to technology had created projects, compared to 58 percent for those who reported no exposure. (See Table 1.) Among the 17 teachers who reported that "all" their faculty in teacher preparation were regular uses of technology, 14 (82.4 percent) of them said they regularly use computers for classroom lessons, pointing to the strong modeling influence (or at least, potential) of the faculty in such institutions.

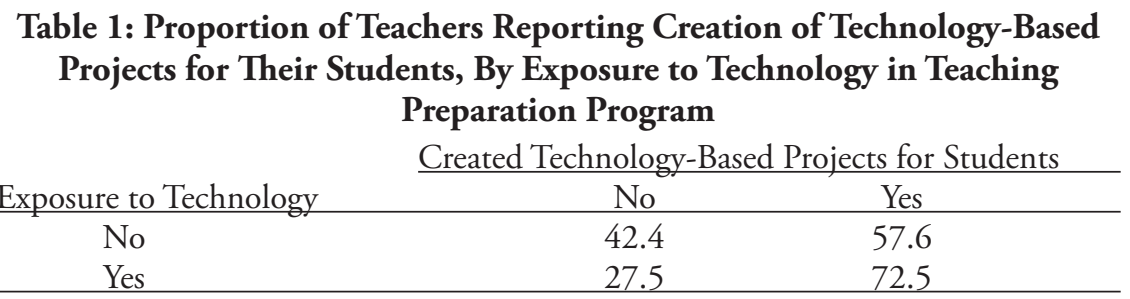

Note: Chi-Square (2) $=4.139, p=.032$

\section{Collegial Environment}

Sandholtz, Ringstaff, and Dwyer (1997) as well as Ringstaff and Kelly (2002) point to the importance of a supportive collegial environment for teachers to integrate technology into their daily practice. To gauge this, the survey asked how often respondents "discuss the use of technology in the classroom with colleagues in your school." Only 8.4 percent of females (and no males) said "never," but a combined 44.4 percent of males and 44.9 percent of females said "once a month" or "less than once a month," thus suggesting that for close to half of the respondents technology was simply not a matter of conversation and productive discussion with peers in their schools. Among males, the proportion reporting higher frequency of discussion (once a week or more often, up to daily) was 44.4 percent (12 out of 30 ), compared to 31.2 percent of females. 
Beyond their colleagues, teachers of both genders either agreed or strongly agreed with the statement "teachers need release time to collaborate with technology support staff to design effective lessons that integrate technology." Among males, 82.2 percent and 93.5 percent of females indicated their preference for sufficient planning time. Similar findings were reported from an online survey of teachers (Murray, 2004, 1 1) that also identified that "a lack of time during the school day, too few school computers, and complex security measures - including school firewalls and filtering systems — are among the biggest impediments to effective technology integration."

\section{Authentic Use of Technology}

The old Chinese saying: "Tell me and I will forget; show me, and I may remember; involve me and I will understand," can be seen as an antecedent to constructivist pedagogy emphasizing student activity and engagement. Jonassen, Howland, Moore, and Marra (2003) are among the many writers arguing for technology use that fits within a broader constructivist philosophy, supporting students' construction of their own knowledge through project-based learning opportunities connected to real-world experiences. They identified five characteristics of "meaningful learning," learning that is active, constructive, cooperative, authentic, and intentional (Jonassen et al., 2003, pp. 6-9). Becker (1994) called it "consequential" work, contrasting it with activities emphasizing "skill mastery and remembered information" that "are significantly different in school than in real life." Boethel and Dimock (1999) conducted a literature review and summarized the positive outcomes on student achievement when technology is integrated into constructivist learning environments. In the present study, a very high proportion of males (89.3 percent) and almost two thirds (64.4 percent) of females said they had created technology-based projects for their students, but the gender pattern is reversed when they expressed agreement or disagreement with a statement as to whether they "prefer project-based learning opportunities over more traditional teacher-directed delivery methods," with a combined 80.7 percent of females either agreeing ( 44 percent) or strongly agreeing (36.7 percent), compared to 46.4 percent of males who agreed and 25 percent who strongly agreed (71.4 percent combined).

The increasing presence of technology in classrooms means that students may have an edge over teachers in terms of knowledge and skills with—plus comfort using - computers. In such situations, the roles of "expert" and "novice" can be reversed, and other research (e.g., Sandholtz, Ringstaff, \& Dwyer, 1997) has shown that some teachers may be uncomfortable with the changes. Overall, it is difficult for teachers to give up entirely their "gatekeeping" or control role when it comes to technology, evidenced by the overwhelming tendency among respondents to either agree ( 40 percent) or strongly agree ( 55 percent) with the statement that "A teacher's proficiency with computers will affect his or her willingness to integrate technology into the curriculum" (see also Christensen, 2002). As noted before, technology proficiency was measured in two different ways. One asked how long the respondent had owned a personal computer, and the other asked respondents to self-rate themselves on eleven different types of 


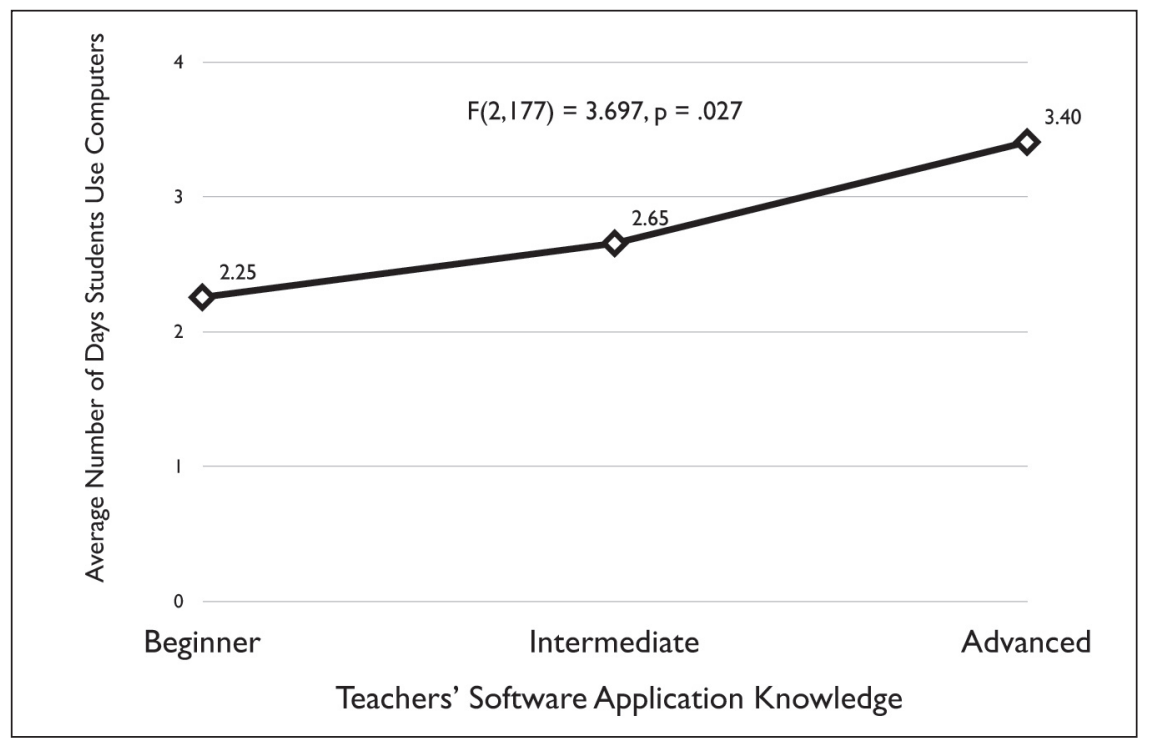

Figure 2. Average Number of Days Students Use Computers, By Teachers' Software Application Knowledge.

software applications. Length of ownership of a PC yielded no significant differences. However, as seen in Figure 2, teachers who had greater application knowledge ( 3 in the scale) had their students using computers on average one more day per week than those who were less knowledgeable.

\section{Constructivist Beliefs}

Changing teachers' beliefs about the nature of learning with technology (Ringstaff \& Kelly, 2002) may be one of the more complex challenges. Eleven items were selected to create a constructivist beliefs scale (Cronbach's alpha $=.79$ ). (See Appendix B, page 64, for the list of items included.) Each item was a four-point Likert scale (Strongly Agree to Strongly Disagree with no neutral point). This scale was the dependent variable in a one-way ANOVA comparing the means of the groups formed by those who answered "yes" $(\mathrm{M}=3.17)$ to the question "Have you ever created technology-based projects for students?" with those who answered "no" $(\mathrm{M}=2.95)(\mathrm{F}(1,171)=16.84, \mathrm{p}=.000)$. Similarly, those who said they integrate technology into their lessons whenever possible $(M=3.19)$ had significantly higher means than their colleagues who did not $(\mathrm{M}=2.97)(\mathrm{F}(1,170)$ $=20.40, \mathrm{p}=.000)$. The frequency with which teachers used technology in their classrooms showed a positive relationship to constructivist beliefs as well, as can be observed in Figure 3. Those who reported using technology 4-5 days per week had a higher mean in the constructivist beliefs scale than those who used it less.

\section{Access to Staff Development and Technical Support}

"Research indicates that teachers' willingness to use computers is influenced by the availability of professional development opportunities and on-site help (Becker, 1994)" (Cited in Hamilton, Klein, \& Lorié, 2000, p. 26). 


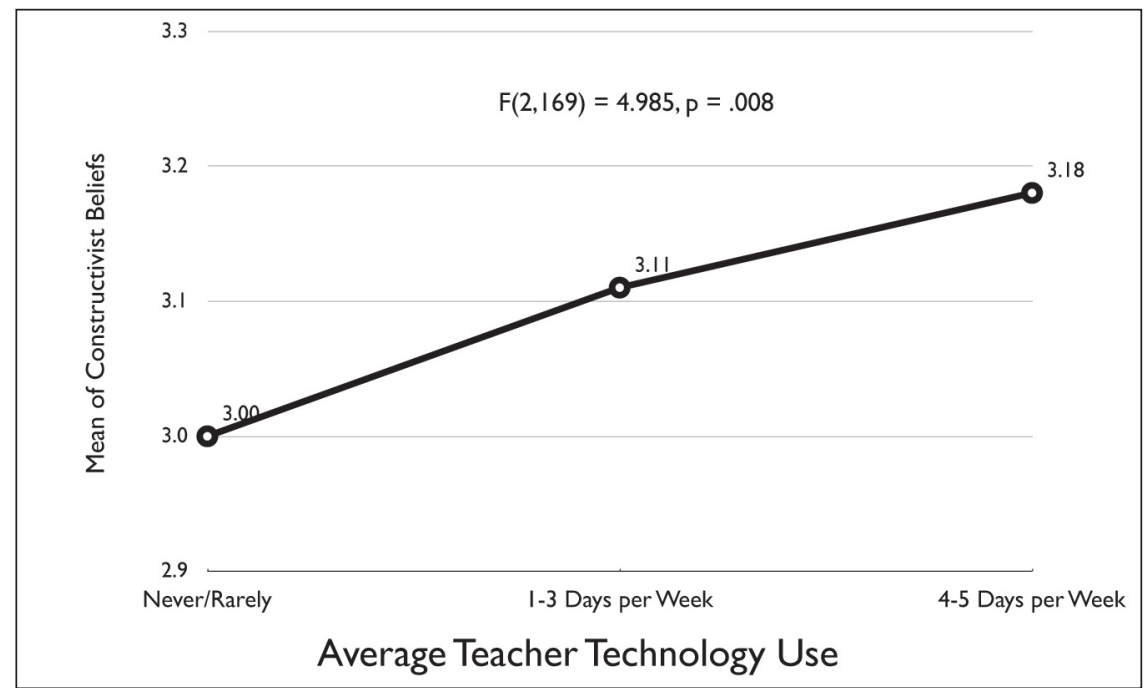

Figure 3. Constructivist Beliefs By Average Number of Days per Week Using Technology in the Classroom.

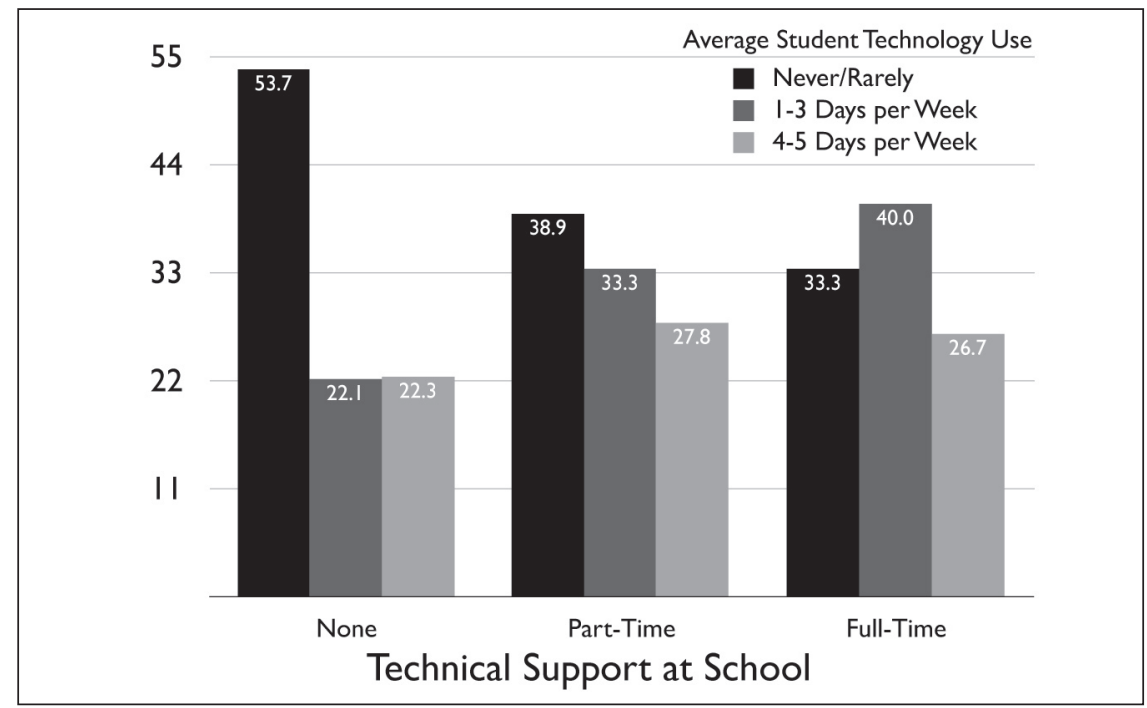

Figure 4. Proportions of Teachers Reporting Average Student Technology Use in Classroom, By Technical Support at School.

Respondents reported differences between their school's support for technology integration and the district's provision of technology-related training. Only 50 percent of females and 57.1 percent of males said their district offered adequate technology training for teachers, but a much higher proportion (87.3 percent of females and 93.1 percent of males) said their schools supported technology integration. However, 28.1 percent of females and 34.5 percent of males said their school did not have technical support staff, half ( 46.7 percent females and 51.7 percent 
males) said the tech staff worked part time, and only 25.1 percent of females and 13.8 percent of males said their schools had full-time technical support staff. This helps explain why 87.2 percent of respondents with no tech support at school said they had to wait days rather than hours to receive technical support.

Figure 4 shows the average number of days students used computers as reported by the teachers (recoded into three categories, "Never/Rarely," "1-3 days a week," and "4-5 days a week") according to the level of technical support available at the school. Although the proportion of teachers having their students use computers 4-5 days a week remains fairly constant at about 25 percent regardless of the level of technical support, the proportion of teachers reporting 1-3 days a week of student use increases from 22.1 percent when there was no technical support to 40 percent with full-time technical support. Conversely, 33.3 percent of the teachers with access to full-time tech support still have their students using technology never or rarely, but this proportion goes up to 53.7 percent in the absence of technical support at school.

A different but related issue is not just the availability of professional development opportunities at either the district or school levels, but actually having the time to attend (Vannatta \& Fordham, 2004). As a reference, a survey of teachers who had received laptops in the Maine Learning Technology Initiative program (Silvernail \& Lane, 2004) found that teachers "feel supported in acquiring these [technical and pedagogical] skills, but the time needed to acquire the skills is very limited" (p. 28). In other words, the amount of planning and learning time formally allocated for teachers' professional development is generally quite low (or non-existent), so even if the classes or courses are offered regularly, true opportunities for attendance may be limited.

\section{DISCUSSION}

The data reported here are suggestive of the personal as well as the contextual factors influencing teachers' decisions to integrate technology into their daily practice. As Ringstaff and Kelly (2002), and Hadley and Sheingold (1990) more than a decade before, observed, some teachers will manage to transform their teaching and create memorable technology-assisted learning experiences with their students despite the institutional, economic, social, political, and even cultural factors that may crop up as obstacles in their paths. For example, about a quarter (27.5 percent) of teachers reporting that they used technology in their classrooms five days a week were doing so in schools with no technical support staff-about the same proportion as teachers working in schools that had fulltime tech support. Unfortunately, the proportion of teachers capable of doing that will remain frustratingly small, even among teachers working in technology-rich Silicon Valley, until all the factors (see above) listed by Ringstaff and Kelly (2002) are systematically addressed in educational policies and practices. And because it is located in California - which has been suffering a budget crisis that has led to the elimination of many technical support positions within schools and districts - the proportion of teachers likely to integrate technology more frequently into their classroom practice is unlikely to increase given the relationship reported here between these two factors. 
Nevertheless, there are examples of schools, both within Silicon Valley and around the country where technology has been seamlessly integrated into the work of teachers, students, and administrators, and where student performance in a wide range of academic measures is, indeed, above average. In Silicon Valley, for example, Sherman Oaks Community Charter School (San José, CA) was designed from the ground up to be a different type of school, serving a largely immigrant and poor population, with plentiful technology available in classrooms, teachers given adequate planning time each day, and students allowed to work in project-based, collaborative groups even in the early grades (George Lucas Educational Foundation, 2000). Also, the "Exemplary Technology-Supported Schooling Cases in the USA" (Anderson \& Dexter, 2003) Web site (http://edtechcases.info/index.htm) presents detailed reports of four elementary, three middle, and three high schools (none in Silicon Valley, although there are several that would qualify) that have been successful for several years integrating technology and maintaining high academic standards. Similarly, the George Lucas Educational Foundation (http://www.edutopia.org) showcases a variety of schools where visionary leadership, dedicated teachers, and a student-centered approach — along with the meaningful integration of technology—come together to create and sustain wonderful learning (and teaching) environments.

The data indicate that when it comes to technology integration, teachers in Silicon Valley are for the most part not very different than their peers elsewhere in California and the rest of the country. This is well illustrated by the very similar results reported here when looking at the proportion of teachers with five or more computers in their classroom who allow frequent (three or more times each week) student use of computers. Becker (2000) reported results of a national survey showing that only 18 percent of teachers with no computers in their classroom allowed "frequent computer experience during class" (2.6 percent in our sample), 32 percent of teachers with $1-4$ computers in their classroom ( 44.7 percent in our sample), and 62 percent of teachers with 5 or more computers in their classroom (64 percent in our sample). These figures suggest that the increased presence and use of student computers in classrooms may be linked more to technology-savvy teachers' constructivist educational philosophies than to the numbers of computers themselves (Becker, 2000). In other words, these constructivist teachers - whether in Silicon Valley or elsewhere-are more likely to have their students doing meaningful work with the computers regardless of the number of machines available to them.

\section{CONCLUSION}

Further statistical analyses of the survey data and additional research will yield more nuanced explanations of teachers' preparation experiences, their understanding of technology for teaching and learning, their perceptions (and specific influence) of the school and district environments (see Achinstein, Ogawa, \& Speiglman, 2004), as well as provide an opportunity to better assess background characteristics in greater detail. Teachers' personality factors such as a preference for order and neatness, resistance to change, and flexibility could influence their decisions on whether to integrate technology into their curriculum using messy, noisy, innovative project-based, collaborative learning opportunities. 
Moving forward, however, this research adds support to the view that technology integration is not a process involving just an individual decision by each teacher. Rather, the recent work of Zhao et al. (2002) clearly makes the case_-articulated differently by Ringstaff and Kelly (2002), Ertmer (1999), and others - that the characteristics of the technology itself and contextual factors largely out of the teachers' control play crucial roles in technology integration decisions and practices. To some degree, given the low emphasis on technology in the majority of teacher preparation institutions, the complexities and problems of the technologies themselves, aging school infrastructures not designed with technology in mind, and the pressures exercised by external stakeholders (e.g., state and federal authorities), the fact that there are any successful examples of meaningful technology integration in schools is something to cheer about. Thus, "reform" efforts should expand their focus to encompass all other relevant stakeholders in the process: teacher preparation programs, school districts, school principals, parent groups, state legislatures, the federal government, business groups, and others.

Arthur (2002, as cited in Norris, Mason, \& Lefrere, 2004) wrote that "A revolution doesn't really arrive until we structure our activities around the new technology — and the new technology adapts to us by becoming easy to use" (p. 70). The large majority of schools (and school systems) have a long way to go before it can be said that they have structured their activities around the possibilities offered by new technology and new(er) pedagogies, to the same degree that industries such as banking or travel (for example) have been fundamentally transformed over the last 10 to 20 years. Whether in Silicon Valley or elsewhere, teachers are only one set of actors among the various stakeholders in the social process called education, and currently they may be the ones holding the least power and influence. Of the seven critical factors listed above by Ringstaff and Kelly (2002), "changing teacher beliefs about teaching and learning" may be the only one assumed to be under teachers' control. For all six other factors, other actors - from the teacher preparation institutions, to principals and the culture they create and sustain in their schools, to district superintendents who decide what levels of financial, personnel, and technical resources to commit, to state and federal officials and agencies that have influence over curriculum and assessment as well as funding_-clearly have more control and power. How that control and power is exercised does have consequences on teachers' technologyrelated practices in their classrooms in Silicon Valley and everywhere.

\section{ACKNOWLEDGEMENTS}

This research was supported by a Presidential Research Grant from Santa Clara University.

\section{Contributor}

Pedro Hernández-Ramos has a joint appointment as assistant professor in the Department of Education and as Program Director in the Center for Science, Technology, and Society at Santa Clara University. His research interests include technology integration in teacher preparation and $\mathrm{K}-12$ education, teach- 
ing and learning with technology, and distributed learning. (Address: Pedro Hernández-Ramos, Department of Education, Santa Clara University, 500 El Camino Real, Santa Clara, CA 95053; phernandezramos@scu.edu.)

\section{References}

Achinstein, B., Ogawa, R. T., \& Speiglman, A. (2004). Are we creating separate and unequal tracks of teachers? The effects of state policy, local conditions, and teacher characteristics on new teacher socialization. American Education Research Journal 41(3), 557-603.

Anderson, R., \& Dexter, S. (2003). Exemplary technology-supported schooling cases in the USA [Web site]. Retrieved October 17, 2004 from http://edtechcases.info/schools.htm.

Apple Classrooms of Tomorrow (ACOT). (1995). Changing the conversation about teaching, learning \& technology. A report on 10 years of ACOT research. $\mathrm{Cu}-$ pertino, CA: Author.

Beaudry, J. S. (2004). The impact of Maine's one-to-one laptop program on middle school teachers and students. Use of laptop computers and classroom assessment: Are teachers making the connections? Research Report \#4. Gorham, ME: Maine Education Policy Research Institute, University of Southern Maine Office.

Becker, H. J. (1994). How exemplary computer-using teachers differ from other teachers: Implications for realizing the potential of computers in schools. Journal of Research on Computing in Education 26(3), 291-322.

Becker, H. J. (2000). Findings from the Teaching, Learning, and Computing survey: Is Larry Cuban right? Education Policy Analysis Archives 8(51). Available: http://epaa.asu.edu.

Boethel, M., \& Dimock, K. V. (1999). Constructing knowledge with technology. A review of the literature. Austin, TX: Southwest Educational Development Laboratory.

Bransford, J. D., Brown, A. L., \& Cocking, R. R. (Eds.) (2000). How people learn. Brain, mind, experience, and school. Washington, DC: National Academy Press.

Christensen, R. (2002). Effects of technology integration education on the attitudes of teachers and students. Journal of Research on Technology in Education 34(4), 411-434.

Cuban, L. (1993). How teachers taught. Constancy and change in American classrooms 1890-1990 (2 ${ }^{\text {nd }}$ ed.). New York: Teachers College Press.

Cuban, L. (2001). Oversold \& underused: Computers in the classroom. Cambridge and London: Harvard University Press.

Cuban, L., Kirkpatrick, H., \& Peck, C. (2001). High access and low use of technologies in high school classrooms: Explaining an apparent paradox. American Educational Research Journal 38(4), 813-834.

Dwyer, D., Ringstaff, C., \& Sandholtz, J. H. (1990a). Teacher beliefs and practices. Part I: Patterns of change. The evolution of teachers' instructional beliefs and practices in high-access-to-technology classrooms. First-fourth year findings. $\mathrm{Cu}-$ pertino, CA: Apple Classrooms of Tomorrow.

Dwyer, D., Ringstaff, C., \& Sandholtz, J. H. (1990b). Teacher beliefs and practices. Part II: Support for change. The evolution of teachers' instructional beliefs 
and practices in high-access-to-technology classrooms. First-fourth year findings. $\mathrm{Cu}-$ pertino, CA: Apple Classrooms of Tomorrow.

Ertmer, P. (1999). Addressing first- and second-order barriers to change: Strategies for technology integration. Educational Technology Research \& Development 47(4), 47-61.

Fisher, C., Dwyer, D., \& Yocam, K. (1996). Education and technology: Reflections on computing in classrooms. San Francisco: Jossey-Bass.

George Lucas Educational Foundation. (2000). Creating a new community school. San Rafael, CA: Author. Retrieved October 14, 2004 from http://www. edutopia.org/php/article.php?id=Art_410.

Hadley, M., \& Sheingold, K. (1990). Accomplished teachers: Integrating computers into classroom practice. New York: Center for Technology in Education, Bank Street College of Education.

Hamilton, L. S., Klein, S. P., \& Lorié, W. (2000) Using web-based testing in large-scale assessment. Santa Monica: RAND Education.

Henrico County Public Schools. (2004). Teaching and learning initiative [Online document]. Retrieved March 14, 2005 from http://www.henrico.k12. va.us/iBook/.

Jonassen, D. H., Howland, J., Moore, J., \& Marra, R. M. (2003). Learning to solve problems with technology: A constructivist perspective. Upper Saddle River, NJ: Merrill.

Kerr, K. A., Pane, J. F., \& Barney, H. (2003). Quaker Valley Digital School District. Early effects and plans for future evaluations. Santa Monica, CA: RAND Corporation.

Marcinkiewickz, H. R. (1993-1994). Computers and teachers: Factors influencing computer use in the classroom. Journal of Research on Computing in Education 26(2), 220-236.

Marvin, C. (1988). When old technologies were new. Thinking about communications in the late nineteenth century. New York and Oxford: Oxford University Press.

Murray, C. (2004) Teachers: Limited time, access cut school tech use. ESchool News online. Retrieved June 24, 2004 from http://eschoolnews.com/news/PFshowstory.cfm?ArticleID=5131.

National Center for Education Statistics (NCES)-Technology in Schools Task Force. (2002). Technology in schools. Suggestions, tools, and guidelines for assessing technology in elementary and secondary education. Washington, DC: Author.

Norris, D., Mason, J., \& Lefrere, P. (2004). Experiencing knowledge. Innovate Journal of Online Education, (1)1. Available: http://www.innovateonline. info/index.php.

Ringstaff, C., \& Kelly, L. (2002). The learning return on our educational technology investment: A review of findings from research. San Francisco: WestEd.

Roblyer, M. D. (2003). Integrating educational technology into teaching. $\left(3^{\text {rd }}\right.$ ed.). Columbus, $\mathrm{OH}$ and Upper Saddle River, NJ: Merrill Prentice Hall.

Sandholtz, J. H. \& Reilly, B. (2004). Teachers, not technicians: Rethinking technical expectations for teachers. Teachers College Record 106(3), 487-512.

Sandholtz, J. H., Ringstaff, C., \& Dwyer, D. (1997). Teaching with technology: Creating student-centered classrooms. New York: Teachers College Press. 
Santa Clara County Office of Education. (2005). Facts about Santa Clara county public schools [Online document]. Retrieved February 20, 2005 from http://www.sccoe.org/newsandfacts/sccpublicschools/.

Silvernail, D. L., \& Lane, D. M. M. (2004). The impact of Maine's one-to-one laptop program on middle school teachers and students. Phase one summary evidence. Research report \#1. Gorham, ME: Maine Education Policy Research Institute, University of Southern Maine Office.

Vannatta, R. A., \& Fordham, N. (2004). Teacher dispositions as predictors of classroom technology use. Journal of Research on Technology in Education 36(3), 253-265.

Yammarino, F., Skinner, S., \& Childers, T. (1991). Understanding mail survey response behavior: A meta-analysis. Public Opinion Quarterly 55(4), 613-640.

Zhao, Y., \& Frank, K. A. (2003). Factors affecting technology uses in schools: An ecological perspective. American Educational Research Journal 40(4), 807840.

Zhao, Y., Pugh, K., Sheldon, S., \& Byers, J. L. (2002). Conditions for classroom technology innovations. Teachers College Record 104(3), 482-515. 


\section{APPENDIX A}

Teachers, Teaching, and Technology

Survey

ID:

Thank you for agreeing to participate in this study. Please be assured that all information gathered will be handled with utmost confidentiality, and respondents will never be personally identified in research reports. Only if you choose to be contacted by the research team for a follow-up interview will we use your personal information, which will not be shared with anyone.

There are no "right" or "wrong" answers to the questions, so please be candid in all your responses to the questions. Please read the instructions at the beginning of each section before answering the questions.

\section{Teaching Background}

1. In what year did you receive your teaching credential? Year

2. From which institution did you receive your teaching credential?

Institution Name

3. Including this year, how many years have you been teaching? Years

4. What grade level are you teaching this year? Grade

5. What other grade levels have you taught in the past, if any?

6. If you have a single subject specialty, what subject(s) do you teach?

7. Including this year, how long have you worked at your current school? Years

8. Prior to teaching, did you have another occupation? _ No _ _ Yes

8.1. If Yes, what was it?

9. Did your teacher preparation experience include exposure to, and use of, technology for teaching and learning? No __ Yes

10. How many of the faculty (professors) in your teacher preparation program used technology (specifically computers) in their classroom?

_ None of them _ 1-2 of them _ 3-4 of them _ Most of them _ All of them

11. During your teacher preparation program, were you expected to use computers for anything other than word processing?

$$
\begin{aligned}
& \text { No } \\
& \text { Yes. For what? }
\end{aligned}
$$

12. During your teacher preparation program, did you ever observe a practicing teacher use technology in his/her classroom in ways that inspired you to learn to do the same?

— No

Yes, more than once 


\section{Technology in Your Classroom}

1. Does your current school provide you with a computer for your personal use in the classroom? _ Yes _ No

1.1 If Yes, does your computer have access to the Internet in your classroom?

$$
\text { Y Yes _ No }
$$

2. Are there working computers in your classroom dedicated for student use? __ Yes

2.1. If Yes, how many? ____ computers

2.2. Are the student computers connected to the Internet?

$$
\text { Y Yes__ Most of them _ Some of them _ No }
$$

3. Please check $(\sqrt{ })$ from the following list all those technology resources available in your classroom:

_Teacher computer _ _ TV _ VCR _ DVD_ _ Student computers

_ Overhead Projector __ Computer Projector___LaserDisc player _ _ CD/Cassette player

__ Other. Please specify:

4. In a typical week, how many days per week do you have students use the computers in class? days per week

5. Does your school have a dedicated computer lab or media center? $\quad \square$ Yes $\square$ No

5.1 If Yes, how many computers does it have? computers

5.2 If Yes, how often do you take your students to the lab?

Times a week Times a month

6. Have you ever used a computer to conduct lessons in your classroom? $\quad \square$ Yes $\square$ No

7. Do you regularly assign homework that requires students to use a computer at home? $\square$ Yes $\square$ No

8. Is there a mobile computer lab at your school? $\quad \square$ Yes $\square$ No

9. Do your students have at least one hour of computer time per week at school? $\square$ Yes $\quad \square$ No

10. Have you ever created technology-based projects for students? $\quad \square$ Yes $\quad \square$ No

11. How often do you discuss the use of technology in the classroom with colleagues in your school?

Never
Less than once a month
Once a month
Every 2-3weeks
Once a week
More than twice a week
Daily

12. Does your school support integrating technology into the classroom? $\quad \square$ Yes $\quad \square$ No $\square$ Don't Know

13. Do you integrate technology into your lesson plans whenever possible? $\quad \square$ Yes $\quad \square$ No

14. On average, how many times per week do you use technology in your classroom lessons? Five days a week Four days a week Three days a week Two days a week _ One day a week _ Rarely Never 


\section{APPENDIX A, CON'T}

15. Do you look for lesson plans or lesson planning resources online? $\quad \square$ Yes $\square$ No

16. Does your school have a technical support staff person? $\quad \square$ Yes, full-time $\quad \square$ Yes, part-time $\quad \square$ None

16.1. If "No" on 16: How many hours after a request for help is placed does technical support typically arrive? hours after request OR_days after request

17. Please check $(\sqrt{ })$ the types of software applications available to your students, either in computers in your classroom or at the school's computer lab, and whether you have ever designed learning activities that allow students to use them.

\begin{tabular}{|l|l|l|}
\hline \multicolumn{1}{|c|}{ Type of Application } & $\begin{array}{c}\text { Available to } \\
\text { students? }\end{array}$ & $\begin{array}{c}\text { Designed } \\
\text { activity } \\
\text { for student } \\
\text { use? }\end{array}$ \\
\hline General productivity (e.g., MS Office, AppleWorks) & & \\
\hline Basic drawing (e.g., KidPix) & & \\
\hline Typing/Keyboarding software (e.g., Type to Learn) & & \\
\hline Multimedia creation (e.g., HyperStudio) & & \\
\hline Concept/mind mapping (e.g., Inspiration) & & \\
\hline Presentation software (e.g., PowerPoint, Keynote) & & \\
\hline CD-ROM Encyclopedias (e.g., WorldBook, Encarta) & & \\
\hline Simple page layout/publishing (e.g., MS Publisher) & & \\
\hline Website design (e.g., Macromedia Studio) & & \\
\hline Digital video (e.g., iMovie, MovieMaker) & & \\
\hline Image/graphics processing (e.g., PhotoShop) & & \\
\hline Illustration/design (e.g., Illustrator) & & \\
\hline Database (e.g., MS Access, FileMaker) & & \\
\hline Simulation software (e.g., SimCity) & & \\
\hline Drill software for reading (e.g., Reader Rabbit) & & \\
\hline Other reading software (e.g., Reading for Meaning) & & \\
\hline Drill software for math (e.g., Math Blaster) & & \\
\hline Other math software (e.g., Graph Club) & & \\
\hline Other. Please name at least one title: & & \\
\hline
\end{tabular}

This space was intentionally left blank. Please proceed to the next page. 


\section{Professional Development}

1. Do you think that your school district provides adequate technical training and support for teachers?

2. For each of the following statements, please check $(\sqrt{ })$ "Yes" or "No".

\begin{tabular}{|c|c|c|}
\hline & YES & No \\
\hline I have been taught software applications relevant to my curriculum level. & & \\
\hline I have participated in hands-on opportunities to use software applications. & & \\
\hline I have observed another educator model how to use a specific software application. & & \\
\hline I have been provided technology lesson ideas relevant to my curriculum level. & & \\
\hline I have been given enough time to practice using applications. & & \\
\hline Technology was an important part of my preservice education program. & & \\
\hline I have received enough instruction on how to use new software applications. & & \\
\hline I have attended technology workshops, seminars, and classes. & & \\
\hline I would like to increase my skills with computers and software. & & \\
\hline I participate in technology learning sessions at least once a month. & & \\
\hline $\begin{array}{l}\text { I have observed another teacher at my school integrating technology in the } \\
\text { classroom. }\end{array}$ & & \\
\hline I would like more training in technology. & & \\
\hline I would like more opportunities to observe other teachers using technology. & & \\
\hline $\begin{array}{l}\text { I believe increasing my training in technology will lead to an increased use of } \\
\text { technology in my classroom. }\end{array}$ & & \\
\hline
\end{tabular}

3. Please indicate the extent to which you agree or disagree with each of the following statements by checking $(\sqrt{ })$ only one of the boxes next to it:

\begin{tabular}{|l|l|l|l|l|}
\hline & $\begin{array}{c}\text { Strongly } \\
\text { Agree }\end{array}$ & Agree & Disagree & $\begin{array}{c}\text { Strongly } \\
\text { Disagree }\end{array}$ \\
\hline $\begin{array}{l}\text { I feel that the school district provides many in-service } \\
\text { opportunities to train teachers to design lessons that } \\
\text { integrate technology. }\end{array}$ & & & & \\
\hline $\begin{array}{l}\text { My pre-service teacher training program included } \\
\text { teaching with technology methodologies that were } \\
\text { beneficial to me. }\end{array}$ & & & & \\
\hline $\begin{array}{l}\text { I think that our administration provides us with adequate } \\
\text { funding to purchase software that we can integrate into } \\
\text { our curriculum. }\end{array}$ & & & & \\
\hline $\begin{array}{l}\text { I believe teachers need release time to collaborate with } \\
\text { technology support staff to design effective lessons that } \\
\text { integrate technology. }\end{array}$ & & & & \\
\hline $\begin{array}{l}\text { I prefer project-based learning opportunities over more } \\
\text { traditional teacher-directed delivery methods. }\end{array}$ & & & & \\
\hline $\begin{array}{l}\text { The best way for teachers to learn about technology } \\
\text { integration is to read books and other print materials on } \\
\text { their own time. }\end{array}$ & & & & \\
\hline $\begin{array}{l}\text { Whenever I have a question about using technology in } \\
\text { the classroom I call a trusted teacher who is an } \\
\text { experienced user. }\end{array}$ & & & & \\
\hline $\begin{array}{l}\text { Teachers should feel comfortable letting their students } \\
\text { teach them about anything related to technology. }\end{array}$ & & & & \\
\hline $\begin{array}{l}\text { The Internet-and the web, in particular-is now the } \\
\text { best medium for me to learn about almost anything. }\end{array}$ & & & & \\
\hline
\end{tabular}




\section{APPENDIX A, CON'T}

\section{Proficiency with Technology}

1. In what setting did you first become reasonably comfortable with using computers? Please check $\sqrt{ }$ only one of the options below:

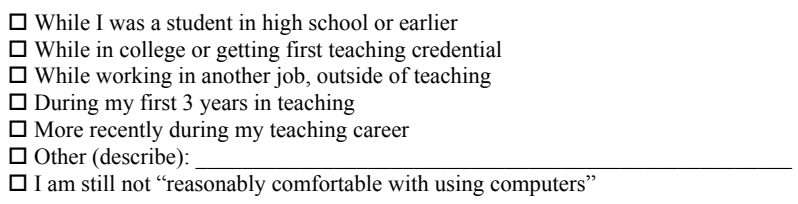

2. For each of the following types of computer applications, please indicate how you rate yourself as a user:

\begin{tabular}{|l|l|l|l|l|}
\hline & $\begin{array}{c}\text { Never } \\
\text { Used }\end{array}$ & Beginner & Intermediate & Advanced \\
\hline Word Processors (e.g., Microsoft Word) & & & & \\
\hline Spreadsheets (e.g., Excel) & & & & \\
\hline Presentation software (e.g., PowerPoint) & & & & \\
\hline E-mail & & & & \\
\hline Searching the Internet (e.g., using Google) & & & & \\
\hline Image processing software (e.g., PhotoShop) & & & & \\
\hline $\begin{array}{l}\text { Taking digital photos and transfer them to the } \\
\text { computer }\end{array}$ & & & & \\
\hline $\begin{array}{l}\text { Downloading and playing music off the } \\
\text { Internet }\end{array}$ & & & & \\
\hline Creating a web page & & & & \\
\hline Maintaining a personal website & & & & \\
\hline $\begin{array}{l}\text { Digitizing ("ripping") a music CD to your } \\
\text { computer for use in a multimedia project }\end{array}$ & & & & \\
\hline
\end{tabular}

3. Do you use the Internet for research (for example, to plan lessons)? $\quad \square$ Yes $\quad \square$ No

4. Do you design learning activities that allow your students to work on technology-based projects? $\square$ Yes $\quad \square$ No

5. Have you ever been asked to teach your colleagues how to integrate technology in the classroom? $\square$ Yes $\square$ No

6. Please indicate the extent to which you agree or disagree with each of the following statements by checking $(\sqrt{ })$ one of the boxes next to it:

\begin{tabular}{|l|c|c|c|c|}
\hline & $\begin{array}{c}\text { Strongly } \\
\text { Agree }\end{array}$ & Agree & Disagree & $\begin{array}{c}\text { Strongly } \\
\text { Disagree }\end{array}$ \\
\hline I feel great confidence in my computer skills & & & & \\
\hline Working with computers makes me anxious & & & & \\
\hline I like learning and working with computers & & & & \\
\hline
\end{tabular}

This space was intentionally left blank. Please proceed to the next page. 


\section{Technology and You}

1. For each of the following statements, please indicate the extent to which you agree or disagree with it by checking $(\sqrt{ })$ only one of the boxes next to it:

\begin{tabular}{|c|c|c|c|c|}
\hline & $\begin{array}{c}\text { Strongly } \\
\text { Agree }\end{array}$ & Agree & Disagree & $\begin{array}{l}\text { Strongly } \\
\text { Disagree }\end{array}$ \\
\hline \multicolumn{5}{|l|}{$\begin{array}{l}\text { Using a computer to communicate with others over a network } \\
\text { (via electronic mail) can help me be more effective at my job. }\end{array}$} \\
\hline \multicolumn{5}{|l|}{ I feel at ease learning about computers. } \\
\hline \multicolumn{5}{|l|}{$\begin{array}{l}\text { Anything a computer can be used for, I can do just as well some } \\
\text { other way. }\end{array}$} \\
\hline \multicolumn{5}{|l|}{ Using computers in my job will only mean more work for me. } \\
\hline \multicolumn{5}{|l|}{$\begin{array}{l}\text { I am anxious about computers in my classroom because I do not } \\
\text { know what to do if something goes wrong. }\end{array}$} \\
\hline \multicolumn{5}{|l|}{$\begin{array}{l}\text { Teachers are better able to present complex materials to } \\
\text { students using technology. }\end{array}$} \\
\hline \multicolumn{5}{|l|}{$\begin{array}{l}\text { With technology, teaching and learning are student-centered } \\
\text { rather than teacher directed. }\end{array}$} \\
\hline \multicolumn{5}{|l|}{$\begin{array}{l}\text { Teachers need to spend more time preparing project-based } \\
\text { learning activities. }\end{array}$} \\
\hline \multicolumn{5}{|l|}{$\begin{array}{l}\text { Teachers are adequately trained in using computers for } \\
\text { instruction. }\end{array}$} \\
\hline \multicolumn{5}{|l|}{$\begin{array}{l}\text { With technology, teachers will spend less time answering } \\
\text { individual questions rather than group questions. }\end{array}$} \\
\hline \multicolumn{5}{|l|}{$\begin{array}{l}\text { A teacher's proficiency with computers will affect his or her } \\
\text { willingness to integrate technology into the curriculum. }\end{array}$} \\
\hline \multicolumn{5}{|l|}{$\begin{array}{l}\text { Our school offers a support system to motivate the faculty to } \\
\text { design lessons that integrate technology into the curriculum. }\end{array}$} \\
\hline \multicolumn{5}{|l|}{$\begin{array}{l}\text { Project-based learning works best when the role of the teacher } \\
\text { is that of facilitator rather than a direct provider of information. }\end{array}$} \\
\hline \multicolumn{5}{|l|}{$\begin{array}{l}\text { Teachers need to manage their classrooms differently when } \\
\text { using project-based learning strategies. }\end{array}$} \\
\hline \multicolumn{5}{|l|}{$\begin{array}{l}\text { Teachers who engage in project-based learning in their } \\
\text { classrooms must change their student assessment procedures. }\end{array}$} \\
\hline \multicolumn{5}{|l|}{$\begin{array}{l}\text { Students should participate in assessing their own work within } \\
\text { project-based learning activities. }\end{array}$} \\
\hline \multicolumn{5}{|l|}{$\begin{array}{l}\text { I feel I have enough training to integrate technology into my } \\
\text { classroom. }\end{array}$} \\
\hline \multicolumn{5}{|l|}{$\begin{array}{l}\text { Computers allow me to better reach students with a variety of } \\
\text { learning styles. }\end{array}$} \\
\hline \multicolumn{5}{|l|}{$\begin{array}{l}\text { Computers assist students with learning goals including } \\
\text { writing, data analysis, and problem solving. }\end{array}$} \\
\hline \multicolumn{5}{|l|}{$\begin{array}{l}\text { Computers integrated into the instructional process provide } \\
\text { students with the ability to work collaboratively. }\end{array}$} \\
\hline \multicolumn{5}{|l|}{$\begin{array}{l}\text { Technology provides me with alternative means to } \\
\text { communicate with my students. }\end{array}$} \\
\hline \multicolumn{5}{|l|}{$\begin{array}{l}\text { Technology provides me with alternative means to } \\
\text { communicate with my colleagues. }\end{array}$} \\
\hline \multicolumn{5}{|l|}{$\begin{array}{l}\text { Technology provides me with alternative means to } \\
\text { communicate with the parents/caretakers of my students. }\end{array}$} \\
\hline $\begin{array}{l}\text { Having students complete assignments with the computer is } \\
\text { preparing them for the } 21^{\text {st }} \text { century workforce. }\end{array}$ & & & & \\
\hline
\end{tabular}




\section{APPENDIX A, CON'T}

\section{About You}

1. For each of the following pairs of terms, check $(\sqrt{ })$ the space between them that best reflects your perception of yourself. For example, in the first pair below, the respondent sees him/herself as being closer to "Happy" than "Sad":

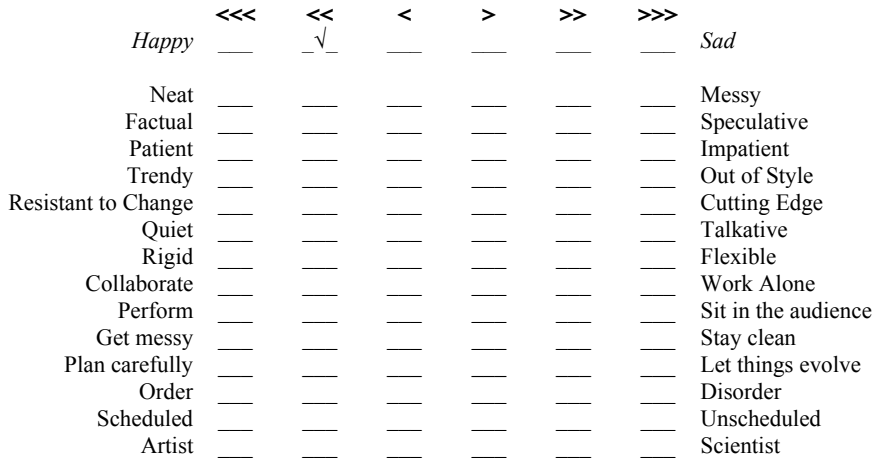

2. "I usually try new products before other people do." $\square$ Yes $\quad \square$ No

3. "I often try new brands because I like variety and get bored with the same old thing?" $\square$ Yes $\square$ No

4. "I see myself as an opinion leader rather than an opinion follower." $\square$ Yes $\square$ No

5. "On my spare time, I do creative projects at home." $\square$ Often $\quad \square$ Sometimes $\quad \square$ Rarely/Never

6. Do you own a personal computer? $\square$ Yes $\square$ No

6.1. If yes, how many years have you owned a personal computer? Years

7. How often do you use your home computer?

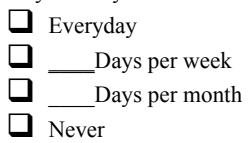

8. What do you use your home computer for? Check all that apply:

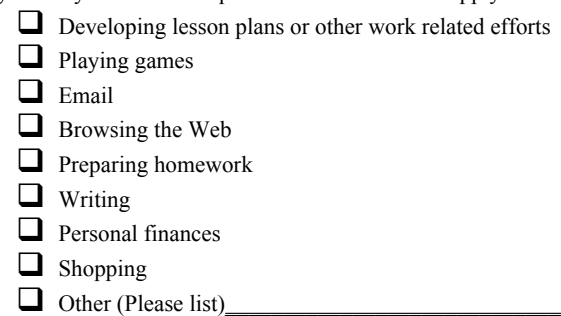

9. Do you have Internet access at home? $\square$ Yes $\square$ No 
10. Please read the following pairs of statements carefully, then check $(\sqrt{ })$ the space between them that you feel best reflects what you are most likely to do or prefer right now:

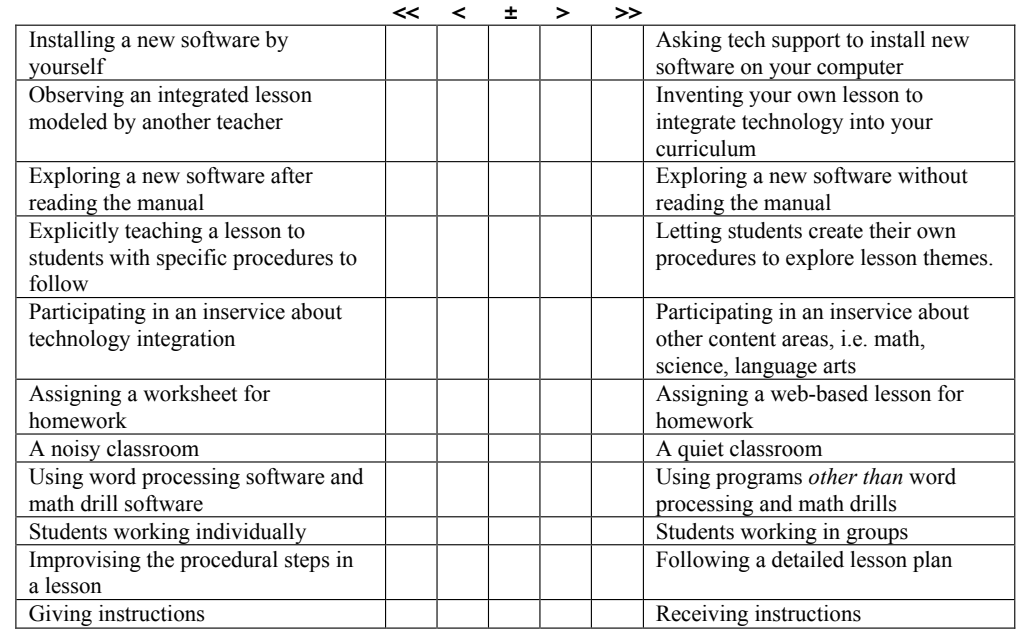

11. What is your gender? $\square$ Female $\square$ Male

12. What is your age on your most recent birthday? Years

13. Where do you teach? City State

14. How would you characterize your school? Urban __ Suburban __ Rural

15. Gross Annual Household Income level: ( $\sqrt{ }$ one $)$ Less than $\$ 20,000$ $\$ 21,000-\$ 40,000$ More than $\$ 80,000$

16. Please indicate your racial/ethnic status (check one)

African American

_ Caucasian (non Hispanic)

- Hispanic

Native American

Asian/Pacific Islander

Other

17. Please indicate the highest degree you have received:

Bachelor's (BA/BS) _ Teaching Credential
Master's (MA/MS)
Doctoral (EdD/PhD)
Other. Please specify:

18. Please indicate your college major:

Thank you, again, for your time answering this questionnaire! 


\section{APPENDIX B}

Items Used to Create the Constructivist Beliefs Scale

"Teachers should feel comfortable letting their students teach them about anything related to technology."

"With technology, teaching and learning are student-centered rather than teacher-directed."

"Teachers need to spend more time preparing project-based learning activities."

"Project-based learning works best when the role of the teacher is that of facilitator rather than a direct provider of information."

"Teachers need to manage their classrooms differently when using projectbased learning strategies."

"Teachers who engage in project-based learning in their classrooms must change their assessment procedures."

"Students should participate in assessing their own work within project-based learning activities."

"Computers allow me to better reach students with a variety of learning styles."

"Computers assist students with learning goals including writing, data analysis, and problem-solving."

"Computers integrated into the instructional process provide students with the ability to work collaboratively."

"Having students complete assignments with the computer is preparing them for the $21^{\text {st }}$ century workforce." 